\title{
Indonesian Economic Structure: An Analysis of Temporal Leontief Inverse
}

\author{
Firmansyah ${ }^{1}$, Shanty Oktavilia ${ }^{2}$ \\ ${ }^{1}$ Faculty of Economics and Business, Diponegoro University, Semarang \\ Jalan Prof. Soedharto SH, Tembalang, Semarang, Jawa Tengah 55283, Indonesia. \\ Telp: +62-024-76486851, E-mail: mr_fmn@yahoo.com \\ 2 Faculty of Economics, Universitas Negeri Semarang \\ Kampus Unnes, Sekaran, Gunung Pati, Semarang, Jawa Tengah 50229 Indonesia \\ Telp: +62-024-8508093, E-mail: oktavilia@yahoo.com
}

Received: February 2015; Accepted: May 2015

\begin{abstract}
This study aims to analyze the Indonesia economic structure with employing the temporal Leontief inverse which was developed by Sonis and Hewings (1998) on 1975-2005 Indonesia's input-output tables. In the first stage, this study investigates how the manufacturing industries in driving the Indonesian economy during structural changes. In the second stage, this study examines the structural changes of the manufacturing industries, which can explain the trends in individual industry balance in the context of the economic system. Based on the analysis, this study can trace how each year's change contributes to the total impact in gross output change.
\end{abstract}

Keywords: input-output table, structural change, temporal Leontief inverse, economic structure JEL classification: $\mathrm{C} 67, \mathrm{O} 11, \mathrm{O} 41$

\section{Struktur Ekonomi Indonesia: Analisis Temporal Leontief Inverse}

\begin{abstract}
Abstrak
Penelitian ini bertujuan menganalisis struktur ekonomi Indonesia dengan menggunakan analisis Temporal Leontief Inverse yang dikembangkan oleh Sonis dan Hewings (1998) pada tabel inputoutput Indonesia tahun 1975-2005. Pada tahap pertama, studi ini mengkaji bagaimana industri manufaktur dalam mendorong perekonomian Indonesia selama perubahan struktural. Pada tahap kedua, penelitian ini meneliti perubahan struktural industri manufaktur, yang dapat menjelaskan tren dalam keseimbangan industri individu dalam konteks sistem ekonomi. Berdasarkan hasil analisis, penelitian ini dapat melacak bagaimana perubahan kontribusi setiap tahunnya terhadap dampak total perubahan output kotor.
\end{abstract}

Kata kunci: input-output, perubahan struktural, temporal Leontief inverse, struktur ekonomi Klasifikasi JEL: C67, O11, O41

\section{Introduction}

As other East Asia's newly industrialized countries (NICs), Indonesian economy growth from the late 1960s, despite experiencing a downward trend in a few years caused by the 1997 Asian economic crisis, was one of the fastest in the contemporary world. The high GDP growth rates, and the significant progress of manufacturing industry, have stimulated the changes in the economic structure of Indonesia. Since the early of 1990s, from initially dominated by the agricultural, ranging from the period, the manufacturing industry has become the industry with the largest contribution to economic output. From very minimal exports and dominated by the agricultural, becoming an export industry which is supported by manufacturing industries. These changes may be attributed to vari- 


\section{Jurnal Ekonomi Pembangunan, 16 (1), Juni 2015, 11-21}

ous causes, such as the growth of the market economy, the increase in consumption and investment, production technological change, and trade.

The purpose of this study is to analyze the characteristics of structural change in the Indonesian economy in the context of inter-industrial linkage during the period 1975-2005. The input-output framework is appropriate for analyzing structural change due to industrial interdependencies of an economy. For Indonesia, this approach has specific advantage that the inputoutput tables provide the most exhaustive (in terms of the coverage of the economy) and detailed (in terms of aggregation) sets of comparable data from 1975 onwards.

To observe the economic structures periodically and inter-industrial linkages at the same time, this study utilizes a relatively new approach, namely the Temporal Leontief Inverse, which was developed by Sonis and Hewings (1998). One of the advantages of the temporal Leontief inverse is the ability to implement and investigate the role of structural changes in a time series of input-output tables (Okuyama et al., 2006). This technique can decompose the impact of final demand on current output into indirect impact in several periods before, so how each year's change contributes to the total impact in gross output change can be traced.

The paper section 2 briefly reviews several studies related to the application of input-output analysis on structural changes. Section 3 briefly describes the data and formula of temporal Leontief inverse which is employed as the main method in this study. Section 4 examines the role of manufacturing industries in driving the economy by applying the direct backward linkage analysis. Section 5 utilizes temporal Leontief inverse to analyze the structural changes of Indonesia economy. The last section is summary.

Survey of Literature on Structural Change and Input-Output Application. Temporal Leontief inverse on input-output data was introduced as a tool to analyze and investigates structural change in an economy over time (Sonis and Hewings, 1998). This method emphasizes on the change of final demand ra- ther than in input-output coefficients were frequently the more important components of output change in a time series evaluation of inputoutput tables. This method, which includes the changes in both final demands and input-output coefficients, investigates how the changes in production affect the evolution of the economic structure. Recent empirical studies such as Guo et al. (2005), and Okuyama et al. (2006), employed this method to analyze structural change in economic of Chicago. Okuyama et al. (2006) utilized the temporal Leontief inverse approach for investigating structural change in the Chicago economy over the period of 1980-1997. They indicated that the Chicago metropolitan economy has experienced a hollowing-out phenomenon, in which the level of dependence on local purchases and sales is declining, especially in the manufacturing industries. The study found that manufacturing sectors have experienced sizable structural changes during the period 1980-1997 with weakening inter industry relationships within the region and becoming more dependent on interregional trade, while services sectors have been rather stable and increasing relative significance in interindustry relationships within the region in the Chicago economy. Guo et al. (2005) integrated two flow decomposition methods to analyze temporal changes in a region's economic structure, i.e. push-pull decomposition analysis and structural Q-analysis. Their study provided an expository application to Chicago's economic structure over the period of 1980 to 2000 , to reveal a complementary perspective of hollowingout the production process in the Chicago economy that was identified in previous studies.

For Indonesian economy, recent empirical studies on structural changes topic are conducted by among others Tambunan (2006), Hayashi (2005), and Jacob (2005). By utilized the Gross Domestic Product (GDP), Tambunan (2006) examined that during the New Order regime (1967-1998), Indonesian economy has been undergone a massive structural change from an economy where the agricultural industries played a dominant role in the country's GDP to an economy and the manufacturing industry has become the industry with the largest con- 
Jurnal Ekonomi Pembangunan, 16 (1), Juni 2015, 11-21

tribution to economic output. Specifically, Hayashi (2005) and Jacob (2005) examined structural changes in Indonesian economy by utilized series of input-output table. Hayashi examined structural changes in Indonesia from the period before to the period after Asian economic crisis 1998 using skyline chart analysis, industrial linkage analysis, and growth factor decomposition analysis. This study employed 1995 and 2000 input-output tables. Results indicate that from 1995 to 2000, the manufacturing industry expanded the share of production, strengthened export orientation, and lowered import dependency. Jacob applied decomposition method to a series table I-O 1975-2000, and analyzed the structural changes and growth of Indonesian economy. His study was divided into three phases of economic development: the inward-oriented phase from 1975 to 1985; the outward-oriented phase from 1985 to 1995; and the recent phase of crisis and recovery from 1995 to 2000. Based on decomposition approach of Indonesia input-output series, Jacob concluded that Indonesian economy grew impressively during the first phase, though still moderate than the second phase. Throughout this two-phase, Indonesia experienced of structural changes, especially in manufacturing. Jacob suggests that the long neglect of the technological foundations and human capital base of the economy could be holding back recovery and sustained growth in the present phase.

This study is different from previous research, particularly research conducted by Jacob (2005). In this paper, the structural change of the Indonesian economy is investigating using the technique of Temporal Leontief Inverse as applied by Sonis and Hewings (1998), while Jacob applied industrial decomposition method as applied by Pyatt and Round (1979). The application of different methods can provide a wealth of research on the topic of structural changes in Indonesia. In addition, this study employs more recent data i.e. 2005 input-output data, expected to provide a latest information on the subject of structural changes of the Indonesian economy.

\section{Research Methods}

\subsection{The Data}

To investigate the structural changes in Indonesia's economy, this study uses Indonesian input-output tables covering the period 19752005. These tables are published by Badan Pusat Statistik (BPS) every five years, which includes 1975, 1980, 1985, 1990, 1995, 2000, and 2005. The type of data used in input-output table is the total transaction based on producer prices, with coverage of 64 industries.

\subsection{The Methodology: Temporal Leontief Inverse}

The analysis of economic structure has created a demand for techniques that can investigate both the nature and changes of the structure over time. Okuyama et al. (2006) noted several techniques include the multiplicative decomposition which applied by Pyatt and Round (1979) and structural path analysis yang that applied by Defourny and Thorbecke (1984). These approaches were applied on social accounting matrices data. Narrowing to the changes of the structure over time, analysis of the evolution of inter-industry relationships has become a major topic for economic analysis. The traditional approach, introduced by Chenery (1953) and Chenery and Watanabe (1958), was further extended in various studies.

The review of some of the earlier approaches to the analysis of structural changes can be reviewed in Okuyama et al. (2006). Okuyama et al. categorized these approaches into the following two: those, like Tiebout (1969), used a comparative static approach; and the others, for example Leontief (1970) and Miernyk et al. (1970), who attempted to form a discrete time-series dynamic system. The Temporal Leontief Inverse method is offered as a substitute of the complexity analysis using formal structures such as dynamics inverse (which involves a change in investment).

The method which used in this paper elaborates technically from the Temporal Leontief Inverse which applied by Sonis and Hewings (1998). In this paper, all formulas are rewrite 


\section{Jurnal Ekonomi Pembangunan, 16 (1), Juni 2015, 11-21}

from Okuyama et al. (2006) which has been summarized in several parts.

According to Okuyama et al. (2006), the framework of the temporal Leontief inverse can be describes as follows. Consider a sequence of time period, $t_{0}, t_{1}, \ldots, t_{T}$, where $t_{0}$ is a initial period and there exist a matrix of direct input coefficient, $\mathbf{A}_{\mathbf{0}}=\left\|a_{i j}^{0}\right\|$, and an associated Leontief inverse matrix, $\mathbf{B}_{\mathbf{0}}=\left(\mathbf{I}-\mathbf{A}_{\mathbf{0}}\right)^{-1}$.In each pe$\operatorname{riod}, t_{s}$, there is the matrix of changes in direct input coefficient, $\mathbf{E}_{\mathbf{s}}=\left\|\boldsymbol{e}_{i j}^{s}\right\|$, such the matrixof direct input coefficients, $\mathbf{A}_{\mathbf{s}}=\left\|a_{i j}^{s}\right\|$, and the Leontief inverse matrix, $\mathbf{B}_{\mathbf{s}}=\left(\mathbf{I}-\mathbf{A}_{\mathbf{s}}\right)^{-1}$, will have the form:

$\mathbf{A}_{\mathrm{s}}=\mathbf{A}_{\mathrm{s}-1}+\mathbf{E}_{\mathrm{s}}=\mathbf{A}_{0}+\mathbf{E}_{1}+\mathbf{E}_{2}+\ldots+\mathbf{E}_{\mathrm{s}}$

$\mathbf{B}_{\mathrm{s}}=\left(\mathbf{I}-\mathbf{A}_{\mathrm{s}-1}-\mathbf{E}_{\mathrm{s}}\right)^{-1}=\left(\mathbf{I}-\mathbf{A}_{\mathbf{0}}-\mathbf{E}_{1}-\mathbf{E}_{2}-\ldots-\mathbf{E}_{\mathrm{s}}\right)^{-1}$

Transforming the latter relationship to a multiplicative form, one can obtain:

$$
\begin{aligned}
\mathbf{B}_{\mathrm{s}}= & \left(\mathbf{I}-\mathbf{A}_{\mathrm{s}-1}-\mathbf{E}_{\mathrm{s}}\right)^{-1}=\left[\left(\mathbf{I}-\mathbf{A}_{\mathrm{s}-1}\right)\left(\mathrm{I}-\mathbf{B}_{\mathrm{s}-1} \mathbf{E}_{\mathbf{s}}\right)\right]^{-1}= \\
& \left(\mathbf{I}-\mathbf{B}_{\mathrm{s}-1} \mathbf{E}_{\mathbf{s}}\right)^{-1} \mathbf{B}_{\mathrm{s}-1}
\end{aligned}
$$

$\mathbf{B}_{\mathbf{s}}=\left(\mathbf{I}-\mathbf{A}_{\mathrm{s}-1}-\mathbf{E}_{\mathrm{s}}\right)^{-1}=\left[\left(\mathbf{I}-\mathbf{E}_{\mathrm{s}} \mathbf{B}_{\mathrm{s}-1}\right)\left(\mathbf{I}-\mathbf{A}_{\mathrm{s}-1}\right)\right]^{-1}=$

$$
\mathbf{B}_{\mathrm{s}-1}\left(\mathbf{I}-\mathbf{E}_{\mathrm{s}} \mathbf{B}_{\mathrm{s}-1}\right)^{-1}
$$

The matrices, $\mathbf{M}_{\mathbf{L}}^{s}=\left(\mathrm{I}-\mathbf{B}_{\mathrm{s}-1} \mathbf{E}_{\mathbf{s}}\right)^{-1}$, dan $\mathbf{M}_{\mathbf{R}}^{s}=$ $\left(\mathbf{I}-\mathbf{E}_{\mathrm{s}} \mathbf{B}_{\mathrm{s}-1}\right)^{-1}$, are called the left and right temporal multiplier. Obviously:

$$
\begin{gathered}
\mathrm{B}_{\mathrm{s}}=\mathbf{M}_{\mathbf{L}}^{s} \mathrm{~B}_{\mathrm{s}-1}=\mathrm{B}_{\mathrm{s}-1} \mathbf{M}_{\mathrm{R}}^{s} ; \mathbf{M}_{\mathbf{L}}^{s}=\mathrm{B}_{\mathrm{s}}\left(\mathrm{I}-\mathrm{A}_{\mathrm{s}-1}\right) \\
\mathbf{M}_{\mathbf{R}}^{s}=\left(\mathrm{I}-\mathrm{A}_{\mathrm{s}-1}\right) \mathrm{B}_{\mathrm{s}}
\end{gathered}
$$

Using left temporal multipliers, the following multiplicative decomposition of the temporal Leontief inverse can be shown as follows:

$$
\begin{aligned}
& =\mathbf{M}_{\mathbf{L}}^{s} \mathbf{M}_{\mathbf{L}}^{s-1} \mathrm{~B}_{\mathrm{s}-2} \\
& =\mathbf{M}_{\mathbf{L}}^{s} \mathbf{M}_{\mathbf{L}}^{s-1} \ldots \mathbf{M}_{\mathbf{L}}^{2} \mathbf{M}_{\mathbf{L}}^{1} \mathrm{~B}_{0}
\end{aligned}
$$$$
\text { : }
$$

The multiplicative representation, model (3), of the Leontief inverse, $\mathbf{B}_{\text {s, }}$ can be converted into the following additive decompotition:

$$
\begin{aligned}
& \mathrm{B}_{\mathrm{s}}=\mathbf{M}_{\mathrm{L}}^{s} \mathrm{~B}_{\mathrm{s}-1}=\mathrm{B}_{\mathrm{s}-1}+\left(\mathbf{M}_{\mathbf{L}}^{s}-\mathrm{I}\right) \mathrm{B}_{\mathrm{s}-1} \\
& \mathrm{~B}_{\mathrm{s}}=\mathrm{B}_{\mathrm{s}-1} \mathbf{M}_{\mathbf{R}}^{s}=\mathrm{B}_{\mathrm{s}-1}+\mathrm{B}_{\mathrm{s}-1}\left(\mathbf{M}_{\mathbf{R}}^{s}-\mathrm{I}\right)
\end{aligned}
$$

Using former relation:

$$
\mathrm{D}_{\mathrm{s}}=\mathrm{B}_{\mathrm{s}}-\mathrm{B}_{\mathrm{s}-1}=\left(\mathbf{M}_{\mathbf{L}}^{s}-\mathrm{I}\right) \mathrm{B}_{\mathrm{s}-1}
$$

$\mathbf{D}_{\mathbf{s}}$, is called as temporal increment, and in turn, provides the additive decomposition of temporal Leontief inverse, as follows:

$$
\begin{aligned}
\mathrm{B}_{\mathrm{s}} & =\mathrm{B}_{\mathrm{s}-1}+\mathrm{D}_{\mathrm{s}} \\
& =\mathrm{B}_{\mathrm{s}-2}+\mathrm{D}_{\mathrm{s}-1}+\mathrm{D}_{\mathrm{s}} \\
\vdots & \\
& =\mathrm{B}_{1}+\mathrm{D}_{2}+\ldots+\mathrm{D}_{\mathrm{s}-1}+\mathrm{D}_{\mathrm{s}} \\
& =\mathrm{B}_{0}+\mathrm{D}_{1}+\mathrm{D}_{2}+\ldots+\mathrm{D}_{\mathrm{s}-1}+\mathrm{D}_{\mathrm{s}}
\end{aligned}
$$

Using left multipliers, $\mathbf{M}_{\mathbf{L}}^{s}$, one can transform the relationship (7) to the following form:

$$
\begin{gathered}
\mathrm{B}_{\mathrm{s}}=\mathrm{I}+(\underbrace{\left.\mathrm{B}_{0}-\mathrm{I}\right)+\left(\mathbf{M}_{\mathbf{L}}^{1}-\mathrm{I}\right) \mathrm{B}_{0}+\left(\mathbf{M}_{\mathbf{L}}^{2}-\mathrm{I}\right) \mathbf{M}_{\mathbf{L}}^{1} \mathrm{~B}_{0}+\ldots}_{+\left(\mathbf{M}_{\mathbf{L}}^{s}-\mathrm{I}\right) \mathbf{M}_{\mathbf{L}}^{s-1} \ldots \mathbf{M}_{\mathbf{L}}^{2} \mathbf{M}_{\mathbf{L}}^{1} \mathrm{~B}_{0}} \\
=\quad \mathrm{B}_{0}+\underbrace{\left.\mathbf{M}_{\mathbf{L}}^{1}-\mathrm{I}\right) \mathrm{B}_{0}+\left(\mathbf{M}_{\mathbf{L}}^{2}-\mathrm{I}\right) \mathbf{M}_{\mathbf{L}}^{1} \mathrm{~B}_{0}+. .}_{+\left(\mathbf{M}_{\mathbf{L}}^{s}-\mathrm{I}\right) \mathbf{M}_{\mathbf{L}}^{s-1} . . \mathbf{M}_{\mathbf{L}}^{2} \mathbf{M}_{\mathbf{L}}^{1} \mathrm{~B}_{0}}
\end{gathered}
$$

$=\mathrm{B}_{1}+\left(\mathbf{M}_{\mathbf{L}}^{2}-\mathrm{I}\right) \mathbf{M}_{\mathbf{L}}^{1} \mathrm{~B}_{0}+. .+\left(\mathbf{M}_{\mathbf{L}}^{s}-\mathrm{I}\right) \mathbf{M}_{\mathbf{L}}^{s-1} . . \mathbf{M}_{\mathbf{L}}^{2} \mathbf{M}_{\mathbf{L}}^{1} \mathrm{~B}_{0}$

$\mathrm{B}_{\mathrm{s}}=\mathbf{M}_{\mathrm{L}}^{s} \mathrm{~B}_{\mathrm{s}-1}$ 
Jurnal Ekonomi Pembangunan, 16 (1), Juni 2015, 11-21

$=$

$=\quad \mathrm{B}_{\mathrm{s}-1}+\left(\mathbf{M}_{\mathbf{L}}^{s}-\mathrm{I}\right) \mathbf{M}_{\mathbf{L}}^{s-1} \ldots \mathbf{M}_{\mathbf{L}}^{2} \mathbf{M}_{\mathbf{L}}^{1} \mathrm{~B}_{0}$

Sonis and Hewings (1998) and Okuyama et al. 2006) claim that this representation provides for interpretation of a temporal inverse Leontief that shares a similar pattern with dynamic model: the inverse depends on it evolutionary tail of changes and this dependence is highly non-linear. The multiplier increment and multiplier temporal together can be used as temporal analysis of an input-output system. For example, if $\mathbf{f}_{\mathbf{s}}$ is a vector of final demand in period $\boldsymbol{s t h}$, and related gross output vector is $\mathbf{x}_{\mathbf{s}}$, which derived as $\mathbf{x}_{\mathbf{s}}=\mathbf{B}_{\mathbf{s}} \mathbf{f}_{\mathbf{s}}$, and then can decomposed into a sum of first time period impact, the second time period, through to the sth time period increments, using the relationship (9), as follows:

$\mathrm{X}_{\mathrm{s}}=\mathrm{B}_{\mathrm{s}} \mathrm{f}_{\mathrm{s}}$

$=\mathbf{f}_{\mathrm{s}}$

$+\left(\mathbf{B}_{0}-\mathbf{I}\right) \mathbf{f}_{\mathrm{s}}$

$+\left(\mathbf{M}_{\mathbf{L}}^{\mathbf{1}}-\mathrm{I}\right) \mathrm{B}_{0} \mathrm{f}_{\mathrm{s}}$

$+\left(\mathbf{M}_{\mathbf{L}}^{2}-\mathrm{I}\right) \mathbf{M}_{\mathbf{L}}^{1} \mathrm{~B}_{0} \mathrm{f}_{\mathrm{s}}$

$+\left(\mathbf{M}_{\mathbf{L}}^{\mathrm{s}}-\mathrm{I}\right) \mathbf{M}_{\mathbf{L}}^{\mathrm{s}-1} \ldots \mathbf{M}_{\mathbf{L}}^{2} \mathbf{M}_{\mathbf{L}}^{1} \mathrm{~B}_{0} \mathrm{f}_{\mathrm{s}}$

Specifically, this formulation can decomposite the impact of final demand change into the direct impact, $\mathbf{f}_{\mathbf{s}}$, the indirect impact at the base year, $\left(\mathbf{B}_{0}-\mathbf{I}\right) \mathbf{f}_{\mathbf{s}}$, the changes (or the deviations from the base year) in indirect impact at the first time period, $\left(\mathbf{M}_{\mathbf{L}}^{\mathbf{1}}-\mathbf{I}\right) \mathbf{B}_{\mathbf{0}} \mathbf{f}_{\mathrm{s}}$, the changes (or deviations from the first period) in indirect impact at the second time period, $\left(\mathbf{M}_{\mathbf{L}}^{2-}\right.$ I) $\mathbf{M}_{\mathbf{L}}^{1} \mathbf{B}_{\mathbf{0}} \mathbf{f}_{\mathbf{s}}$, and so forth. In this formula, how each year's change contributes to the total impact in gross output change can be traced.

Equation (9) can be used to analyze changes in the impact path from the increase or decrease in final demand at a particular time period. Using Equations (5) and (6), Equation (9) can be simplified for numerical calculation as follows:

\section{Results}

\subsection{Manufacturing Industries Link- ages in Indonesian Economy}

Based on real GDP, since the early of 1990s, from initially dominated by the agricultural, ranging from the period, the manufacturing has become the industry with the largest contribution to Indonesian economic (Badan Pusat Statistik, 2005). With utilizes the series of input-output data (1975-2005), Figure 1 shows the output trend of 10 largest manufacturing industries (which have largest output after 1990). The manufacturing classification which is used in this analysis is represented as code 27-54 in Appendix 1.

The output level among these industries are varies (see Figure 1); for example, the largest output industry, the Manufacture of textile, wearing apparel and leather (36), has the largest output compared to other industries since 1990. On the other hand, the Manufacture of food processing and preserving (27), has a significant increase between 1990 and 2000, and grows at highest rate than other manufacturing industries. The manufacture of other products not elsewhere classified industries (50) has smallest output among 9 other industries, but still has significant output growth during 19902005. 
Jurnal Ekonomi Pembangunan, 16 (1), Juni 2015, 11-21

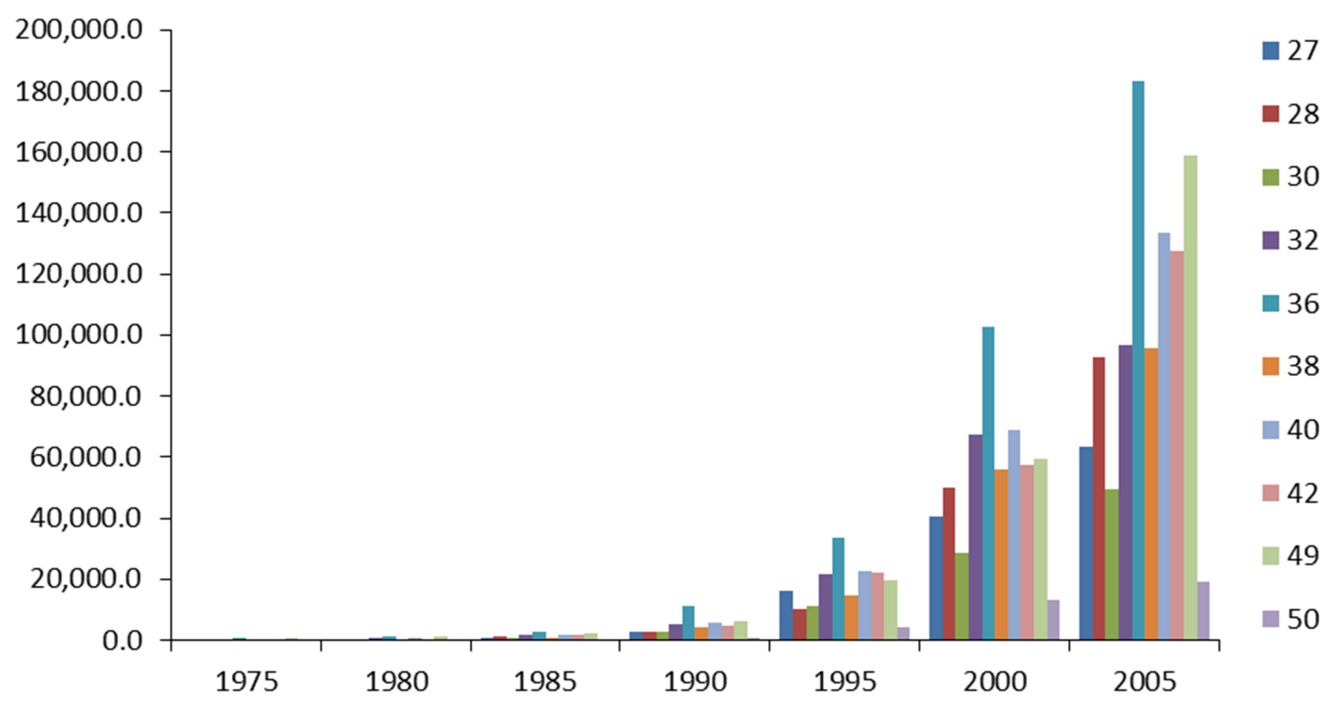

Figure 1. Output of 10 Manufacturing Industries 1975-2005 (billion rupiahs)

Production activities in one industry may have effects that directly and indirectly induce those in other industries. Directly, the increase of output in one industry can increase the output in other industries through its input demand. This effect can be measured from the direct input coefficient of an industry. The larger the input coefficient of an industry, the greater the ability of the industry to directly affects the economy. Figure 2 displays the trend of direct input coefficients of 10 largest manufacturing industries. During 1990-2005, the num- bers of direct input coefficients of the 10 industries are almost the same. However, the six industries have decline trend of input coefficient along 1975-2005, i.e. industry 27, 28, 30, 32, 36, and 49 .

Based on the figures of direct input coefficients, industries that have highest direct input coefficients along 1975-2005 are Rice milling (29), Manufacture of food processing and preserving (27), Manufacture of rubber and plastic wares (42), and Manufacture of non-ferrous basic metal industries (46). The impact of the

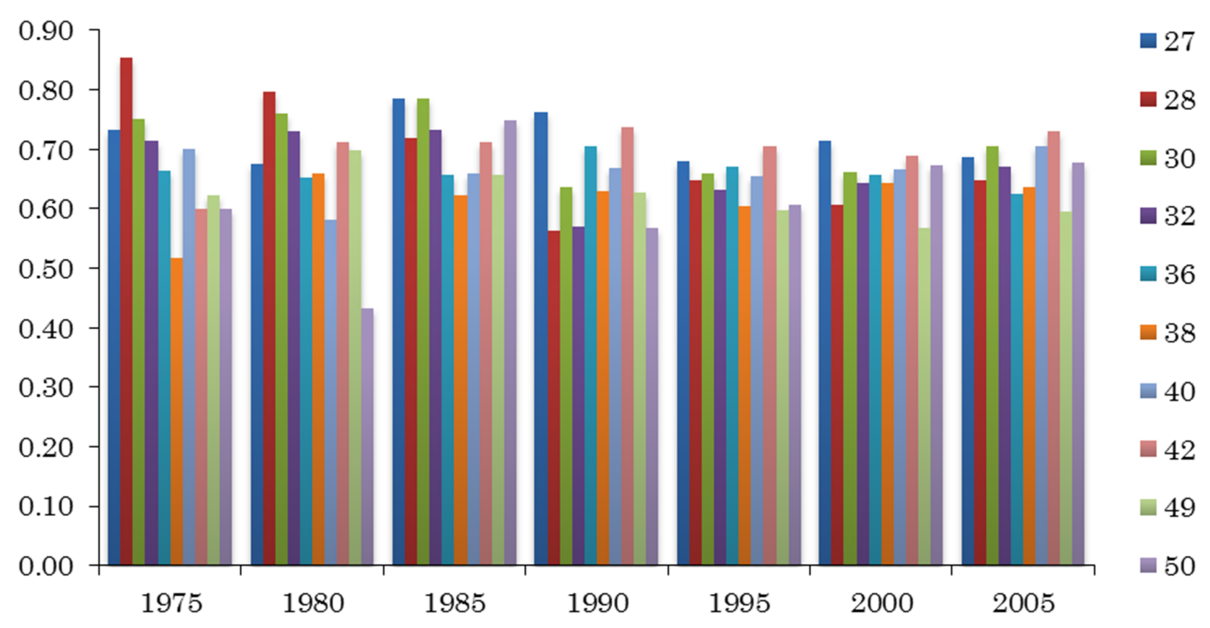

Figure 2. Direct Backward Linkage of 10 Manufacturing Industries 1975-2005 


\section{Jurnal Ekonomi Pembangunan, 16 (1), Juni 2015, 11-21}

increasing of output in these industries due to the increase of final demand has the largest impact compared to other industries. Several industries such as Sugar factory (31), Manufacture of textile, wearing apparel and leather (36), Manufacture of fertilizer and pesticide (39), Manufacture of chemical (40) and Manufacture of machine, electrical machinery and apparatus industry (48) have high input coefficients since 1990. These industries can be said as the leading industries after structural change in 1990s, compared to other industries.

Industries that never included in the top 10 highest direct input coefficients along 19752005 are Manufacture of beverages (33), Manufacture of cigarettes (34), Manufacture of paper, paper products and cardboard (38), Manufacture of non metallic mineral products (43), Manufacture of cement (44). Manufacture of oil and fat (28), Manufacture of flour, all kinds (30), Manufacture of other food product (32) and Petroleum refinery (41) are not include in top 10 highest direct input coefficients after 1990, see Figure 2.

The movement of the production activities of these industries was heavily influenced by government policies during 1975-2005. Policies implemented by governments inevitably affected the structure of the input of manufacturing industries. Up to the 1997 Asian economic crisis, the government's new order regime (19671998) was implemented a series of policy that was focused on manufacturing industries, by is- suing and implementing a series of regulations such as investment, exports, taxation and protection policies, especially since 1980 s. The decrease of world oil prices and the recession that hit the industrial countries in 1982-1983, had affected significantly to drop Indonesian economy, and the sub sequent impact of changes in economic structure. The fall in oil prices coupled with a slowing down of economic growth during the period 1982-86, caused a policy response of liberalization and opening up. The government implemented the budget reduction, increased the foreign loans, promoted the export of non-oil and gas commodities, limited the import of luxury goods, reduced the trips to abroad, encouraged the use of domestic products, and rescheduled and even canceled about 50 public sector projects (which were capital and import intensive). In 1984, the government reduced various subsidies on fuel, fertilizers and pesticides. A series of new laws on taxation imposed since January 1984. In the monetary sector, the government issued a policy that led the Indonesian economy to the market mechanism, namely Policy Package 1 June 1983 (Pakjun 83), which aimed to promote the independence of the banking system. As a result, in addition to improve the public deposits in banks, Pakjun 83 also contributed positively to monetary stability and supported the development of real sector. Since 1980 s, the role of export of non-oil and gas based manufacturing, continued to encourage by the government.

Table1.Temporal Impacts of the Demand Increase in 10 Manufacturing Industries

\begin{tabular}{cccccccrrr}
\hline IO Code & $\Delta \mathrm{X}_{\mathrm{s}}$ & $\Delta \mathrm{f}_{\mathrm{s}}$ & $\left(\mathrm{B}_{0}-\mathrm{I}\right) \Delta \mathrm{f}_{\mathrm{s}}$ & $\mathrm{D}_{1} \Delta \mathrm{f}_{\mathrm{s}}$ & $\mathrm{D}_{2} \Delta \mathrm{f}_{\mathrm{s}}$ & $\mathrm{D}_{3} \Delta \mathrm{f}_{\mathrm{s}}$ & $\mathrm{D}_{4} \Delta \mathrm{f}_{\mathrm{s}}$ & $\mathrm{D}_{5} \Delta \mathrm{f}_{\mathrm{s}}$ & $\mathrm{D}_{6} \Delta \mathrm{f}_{\mathrm{s}}$ \\
\hline 27 & 2.167 & 1 & 1.348 & -0.113 & -0.904 & 0.891 & -0.152 & 0.123 & -0.025 \\
28 & 2.263 & 1 & 1.275 & -0.160 & -0.570 & 0.347 & 0.156 & 0.060 & 0.157 \\
30 & 2.297 & 1 & 1.266 & -0.014 & -0.285 & 0.060 & 0.044 & 0.101 & 0.126 \\
32 & 2.223 & 1 & 1.020 & 0.117 & -0.296 & 0.053 & 0.143 & 0.057 & 0.128 \\
36 & 2.359 & 1 & 1.439 & -0.029 & -0.337 & 0.517 & -0.118 & -0.196 & 0.083 \\
38 & 2.366 & 1 & 0.988 & 0.331 & -1.140 & 1.123 & -0.097 & 0.073 & 0.087 \\
40 & 2.209 & 1 & 1.510 & -0.389 & -0.289 & 0.597 & -0.056 & -0.345 & 0.180 \\
42 & 2.441 & 1 & 1.342 & 0.120 & -0.707 & 0.806 & -0.123 & -0.206 & 0.209 \\
49 & 2.353 & 1 & 1.317 & 0.505 & -0.676 & 0.268 & -0.127 & -0.148 & 0.214 \\
50 & 2.424 & 1 & 1.074 & -0.258 & -0.521 & 0.896 & 0.046 & 0.058 & 0.129 \\
\hline
\end{tabular}

Note: Subscript s represents 2005; subscript 0 represents the basic year $1975 . \mathrm{D}_{1}=\mathrm{B}_{1980}-\mathrm{B}_{1975 .} \mathrm{D}_{2}=\mathrm{B}_{1985}$ $\mathrm{B}_{1980} . \mathrm{D}_{3}=\mathrm{B}_{1990}-\mathrm{B}_{1985} . \mathrm{D}_{4}=\mathrm{B}_{1995}-\mathrm{B}_{1990} . \mathrm{D}_{5}=\mathrm{B}_{2000}-\mathrm{B}_{1995}$, and $\mathrm{D}_{6}=\mathrm{B}_{2005}-\mathrm{B}_{2000}$. 


\section{Jurnal Ekonomi Pembangunan, 16 (1), Juni 2015, 11-21}

\subsection{Temporal Leontief Inverse Analy- sis of Structural Change of Indonesian Economy}

Using the formulation of the temporal inverse, Equation (10), an impact of final demand increase in 2005 to a specific industry can be decomposed to the temporal impact (each year's contribution to the total system-wide impact), so that structural changes in each year, in terms of inter-industrial relationship, can be traced. First, final demand for Manufacture of food processing and preserving (27); the highest output growth industry after 1990, is increased Rp1 million. Such improvements increase the output of industry which the code is 27 , or industry 27 , in 2005 by 2.167 million rupiahs, decomposed into the direct impact of changes in final demand is equal to one million rupiahs, indirect impacts in the base year (1975) by 1.348 million rupiahs, the indirect impact of changes in the first period (1975-1980) by -0.113 million rupiahs, the indirect impact of changes in the second period (1980-1985) by -0.904 million rupiahs, the indirect impact of changes in the third period (1985-1990) around 0.891 million rupiahs, the indirect impact of changes in the fourth period (1990-1995) by -0.152 million rupiahs, the indirect impact of changes in the fifth period (1995-2000) by 0.123 million rupiahs, and indirect impacts of change in the sixth period (2000-2005) by -0.025 million rupiahs (Table 1). From these results, it can be analyzed that the change in output that occurred in industry 27 was contributed by the indirect impact of changes in the third period (19901985), in addition to the indirect impact of the base year. Notice that the negative numbers in this figure are the relative decline in interindustrial relationship comparing to the previous year. In addition to the third period, the positive contribution so occurs in the fifth (19952000).

In Table 1 can be seen that the change in the output of each nine other industries due to an increase in final demand also have the same interpretation with the industry 27. Indirect impact of changes in the third period of each industry are positive and this period as the largest contributor to the output of each industry in 2005. This suggests that economic conditions improved rapidly after the recession due to falling of oil prices in the early 1980s.

A further fall in oil prices in 1986 required the government to implement microeconomic

Table 2. Five Largest Industries Contributor of the Temporal Impacts in 10 Manufacturing Industries

\begin{tabular}{ccccccc}
\hline IO Code & $\mathrm{D}_{1} \Delta \mathrm{f}_{\mathrm{s}}$ & $\mathrm{D}_{2} \Delta \mathrm{f}_{\mathrm{s}}$ & $\mathrm{D}_{3} \Delta \mathrm{f}_{\mathrm{s}}$ & $\mathrm{D}_{4} \Delta \mathrm{f}_{\mathrm{s}}$ & $\mathrm{D}_{5} \Delta \mathrm{f}_{\mathrm{s}}$ & $\mathrm{D}_{6} \Delta \mathrm{f}_{\mathrm{s}}$ \\
\hline 27 & $18,8,9,10,42$ & $23,6,32,15,20$ & $49,23,48,40,42$ & $5,62,59,28,9$ & $53,23,27,28,25$ & $55,5,60,27,48$ \\
28 & $10,63,39,56,25$ & $10,39,16,53,28$ & $28,48,49,40,42$ & $28,9,10,17,53$ & $28,53,3,25,62$ & $10,60,28,55,39$ \\
30 & $6,29,4,1,9$ & $6,39,4,19,26$ & $3,30,49,48,31$ & $4,30,3,1,29$ & $53,30,28,62,20$ & $6,30,39,32,55$ \\
32 & $8,30,13,25,53$ & $1,29,16,3,4$ & $2,49,12,48,40$ & $32,31,16,53,56$ & $53,25,28,27,6$ & $3,32,55,60,12$ \\
36 & $40,42,25,19,18$ & $35,40,53,61,20$ & $40,35,49,48,36$ & $62,36,42,59,61$ & $53,15,25,7,24$ & $36,48,41,55,60$ \\
38 & $38,53,56,63,42$ & $26,55,30,6,15$ & $40,35,49,48,36$ & $62,38,21,56,59$ & $53,25,24,62,41$ & $55,40,38,41,48$ \\
40 & $38,42,14,63,50$ & $40,43,32,24,27$ & $40,48,49,62,51$ & $62,59,42,56,38$ & $25,53,24,7,49$ & $40,25,48,63,41$ \\
42 & $40,42,38,53,56$ & $42,7,39,16,27$ & $40,48,49,63,62$ & $62,56,59,48,60$ & $25,53,24,41,49$ & $40,48,41,60,7$ \\
49 & $49,45,56,50,63$ & $48,61,47,46,55$ & $45,48,40,42,51$ & $42,62,46,49,56$ & $53,25,62,51,38$ & $49,48,45,55,60$ \\
50 & $50,45,63,47,36$ & $40,50,46,20,33$ & $49,48,42,62,46$ & $46,4,50,62,59$ & $53,25,15,61,57$ & $48,55,41,60,50$ \\
\hline
\end{tabular}

Note: Code description and classification of industries are provided in Appendix 1. 


\section{Jurnal Ekonomi Pembangunan, 16 (1), Juni 2015, 11-21}

reforms, which enhanced export-oriented manufacturing and foreign direct investment (Hayashi, 2005). The government policies contributed to the acceleration of economic growth until just before 1997-1998 economic crises. According to Hayashi, during the decade from 1986, Indonesia's annual average growth in GDP exceeded 8 percent. This was driven by a rapid expansion of the manufacturing industry, which contributed to more than 30 percent of the total growth. This high economic growth, along with deregulation measures, stimulated business activities in the private sector.

Post-crisis economic recovery can be witnessed through the indirect impact of changes in the fifth period $\left(\mathrm{D}_{5}\right)$ and the sixth period $\left(\mathrm{D}_{6}\right)$, which also contributed positively to the output of each industry in 2005, except in some industries at $D_{5}$ that have a negative number. These industries are experiencing the indirect impact of a decrease from 1995 to 2000, which is expected weakening of the linkages these industries as the effects of the crisis of 1998. In 2005, this condition has been improved by the positive contribution of the indirect impact of changes in the sixth period.

In more detail, in each industry can be observed the changes in the structure of five largest indirect impact recipient industries. The pattern that occurs is almost similar for the manufacturing to the entire economy. For the industry 27, in the decomposition of impact $\mathbf{D}_{1} \Delta \mathbf{f}_{\mathbf{s}}$, the five industries that accounted for the greatest impact are $18,8,9,10$, and 42 . The five largest contributors to the changes of indirect impact $\mathbf{D}_{\mathbf{2}} \Delta \mathbf{f}_{\mathrm{s}}$ on industry 27 are industry 23,6 , 32,15 and 20 , and so forth. Table $2^{1}$ is a summary of five largest industries that contribute the temporal impacts on each 10 manufacturing industries.

Contribution of changes of indirect impact in the third period for all manufacturing industries was contributed mainly by the industry 40 , 48 , and 49 , with a consistently high rate of

${ }^{1}$ Direct impact, $\Delta \mathbf{f}_{\mathrm{s}}$, and the base year (1975) indirect impact, $\left(\mathbf{B}_{\mathbf{0}}-\mathbf{I}\right) \mathbf{\Delta} \mathbf{f}_{\text {sare }}$ not included in this and following figures in order to emphasize temporal changes between 1980 and 2005. change in each manufacturing industry. While the contribution of changes of indirect impact in fifth period is consistently contributed by industry 25 and 53. For the changes of indirect impact in period six, industry 48 is a most frequent contribute in every industries.

\section{Conclusions}

This study analyzes the characteristics of structural change in the Indonesian economy with utilized Temporal Leontief Inverse on the series of input-output tables during 1975-2005. While the methodology and associated properties of the temporal Leontief inverse do not provide the rich theoretical foundations that the Leontief dynamic system and its extended and modified models offer, the technique provides the capability for implementation and for exploration of the analysis of structural changes in a time series of input-output tables.

With the decomposition of temporal inverse, this study examines numerically in which year temporal change is more significant impact on the system-wide economic structure than in other years. Consequently, temporal inverse can analyze changes in the system-wide impact of the changes in a particular industry and can illustrate the trends of changes in indirect impact.

This study finds that the interactions between industries (direct input coefficient) especially several manufacturing industries have declining trends, implying that direct backward linkage of these industries in the Indonesian economy becomes weakening. However these impacts are covered by the total backward linkage for manufacturing industries generally.

With utilization of Temporal Leontief Inverse analysis, it is known that the increasing of the manufacturing industries output as a result of current changes in final demand, in addition to contributed directly by the final demand, is also mainly contributed by the indirect impact of changes in the third period (1985-1990). This suggests that economic conditions improved rapidly after the recession due to oil prices falling in the early 1980s, and drive by 


\section{Jurnal Ekonomi Pembangunan, 16 (1), Juni 2015, 11-21}

macroeconomic policy reforms which enhanced export-oriented manufacturing and foreign direct investment. In addition, the economic recovery after the 1997-1998 crisis supports the indirect contribution in the fifth (1995-2000) and sixth (2000-2005) period to the positive changes in output of manufacturing industries.

Based on the tracing of the direct impact of changes in each positive period, it was found that there are some unique industries that are consistently deliver the largest contribution to the indirect impacts of each period, such as industry 40, 48, and 49 in the indirect impact of changes in the third period.

\section{References}

Badan Pusat Statistik. 2005. Statistik 60 tahun Indonesia merdeka, Jakarta: Badan Pusat Statistik.

Badan Pusat Statistik. Various years. Indonesian input-output table, Jakarta: Badan Pusat Statistik.

Chenery, H.B. and T. Watanabe. 1958. International comparisons of the structure of production, Econometrica 26:487-521, Quoted in Okuyama, Y., M. Sonis and G.J.D. Hewings, (2006).

Defourny, J., and E. Thorbecke. 1984. Structural path analysis and multiplier decomposition within a social accounting matrix framework", Economic Journal 94: 111136.

Guo, D., G.J.D. Hewings, and M. Sonis. 2005. Integrating decomposition approaches for the analysis of temporal changes in economic structure: an application to Chicago's economy from 1980 to 2000", Economic Systems Research 17, No. 3 (September): 297-315.

Hayashi, M. 2004. Structural changes in Indonesian industry and trade: an input-output analysis. The developing economies, XLIII-1: 39-71 [www document] http: //www.ide.go.jp/English/Publish/Periodi-
cals/De/pdf/05_01_03.pdf, accessed $3 \mathrm{Au-}$ gust 2011, 10.30 west Indonesian time.

Jacob, J. 2005. Late industrialization and structural change: Indonesia, 1975-2000, $O x$ ford Development Studies 33, No. 3\&4 (September-December): 297-315

Leontief, W. 1970. The dynamic inverse, in A. P. Carter and A. Brody eds, Contributions to input-output analysis, Amsterdam, Netherlands: North-Holland publishing; 17-46. Quoted in Okuyama, Y., M. Sonis and G.J.D. Hewings (2006)

Miernyk, W.H., K.L. Shellhammer, R.L. Coccari, W.H. Wineman, C.J. Gallagher, and D.M. Brown. 1970. Simulating economic development, Lexington, MA: Lexington Books. Quoted in Okuyama, Y., M. Sonis and G.J.D. Hewings, (2006)

Okuyama, Y., M. Sonis and G.J.D. Hewings. 2006. Typology of structural change in a regional economy: a temporal inverse analysis, Economic Systems Research 18, No. 2 (June): 133-153.

Pyatt, G. and J.I. Round. 1979. Accounting and fixed price multipliers in a Social Accounting matrix framework, Economic Journal 89: 850-73, Quoted in Okuyama, Yasuhide, M. Sonis and G.J.D. Hewings (2006).

Sonis, M., and G.J.D. Hewings. 1998. Temporal Leontief inverse. Macroeconomic Dynamics, 2, 1998:89-114. [www document] http: //journals.cambridge. org.dbgw.lis.curtin.edu.au/, accessed 30 July 2011, 13.00 west Indonesian time

Tiebout, C.M. 1969. An empirical regional input-output projection model: the State of Washington, 1980, Review of Economics and Statistics, 51, 334-340. Quoted in Okuyama, Y., M. Sonis and G.J.D. Hewings (2006)

Tambunan, T. 2006. Long term trends in the industrial and economic growth in Indo- 
Jurnal Ekonomi Pembangunan, 16 (1), Juni 2015, 11-21

nesia, working paper series No.11 Center for industry and SME studies (September), [www document] http://www.fe. trisakti.ac.id/pusatstudi_industri/, accessed
3 August 2011, 09.25 west Indonesian time.

\section{Appendix}

Appendix 1. IO Classification and Codes of Industries in Indonesia

\begin{tabular}{|c|c|c|c|}
\hline Code & Definition & Code & Definition \\
\hline 1 & Paddy & 33 & Manufacture of beverages \\
\hline 2 & Beans & 34 & Manufacture of cigarettes \\
\hline 3 & Maize & 35 & Yarn spinning \\
\hline 4 & Roots crops & 36 & Manufacture of textile, wearing apparel and leather \\
\hline 5 & Vegetables and fruits & 37 & Manufacture of bamboo, wood and rattan product \\
\hline 6 & Other food crops & 38 & Manufacture of paper, paper products and cardboard \\
\hline 7 & Rubber & 39 & Manufacture of fertilizer and pesticide \\
\hline 8 & Sugarcane & 40 & Manufacture of chemical \\
\hline 9 & Coconut & 41 & Petroleum refinery \\
\hline 10 & Oil Palm & 42 & Manufacture of rubber and plastic wares \\
\hline 11 & Tobacco & 43 & Manufacture of non metallic mineral products \\
\hline 12 & Coffee & 44 & Manufacture of cement \\
\hline 13 & Tea & 45 & Manufacture of basic iron and steel \\
\hline 14 & Clove & 46 & Manufacture of non ferrous basic metal \\
\hline 15 & Fibber crops & 47 & Manufacture of fabricated metal products \\
\hline 16 & Other estate crops & 48 & $\begin{array}{l}\text { Manufacture of machine, electrical machinery and } \\
\text { apparatus }\end{array}$ \\
\hline 17 & Other agriculture & 49 & Manufacture of transport equipment and its repair \\
\hline 18 & Livestock & 50 & Manufacture of other products not elsewhere classified \\
\hline 19 & Slaughtering & 51 & Electricity, gas and water supply \\
\hline 20 & Poultry and its products & 52 & Construction \\
\hline 21 & Wood & 53 & Trade \\
\hline 22 & Other forest product & 54 & Restaurant and hotel \\
\hline 23 & Fishery & 55 & Railway transport \\
\hline 24 & Coal and metal ore mining & 56 & Road transport \\
\hline 25 & $\begin{array}{l}\text { Crude oil, natural gas and } \\
\text { geothermal mining }\end{array}$ & 57 & Water transport \\
\hline 26 & Other mining and quarrying & 58 & Air transport \\
\hline 27 & $\begin{array}{l}\text { Manufacture of food processing and } \\
\text { preserving }\end{array}$ & 59 & Services allied to transport \\
\hline 28 & Manufacture of oil and fat & 60 & Communication \\
\hline 29 & Rice milling & 61 & Financial intermediaries \\
\hline 30 & Manufacture of flour, all kinds & 62 & Real estate and business services \\
\hline 31 & Sugar factory & 63 & General government and defense, and other services \\
\hline 32 & Manufacture of other food product & 64 & Social community services \\
\hline
\end{tabular}

